\title{
Artigos
}

\section{DEIXAR-SE ENGANAR}

\section{TO LET YOURSELF BE FOOLED}

\author{
DEJARSE ENGAÑAR
}

\section{Ana Julia Marko}

\begin{abstract}
Ana Julia Marko
Mestre em Pedagogia do Teatro. Professora substituta de disciplinas na área de Teatro e Educação na ECA-USP e coordenadora pedagógica da escola profissionalizante Incenna.
\end{abstract}




\section{Resumo}

Este artigo analisa uma experiência realizada com participantes de um processo pedagógico a partir da exposição do artifício cênico e da mentira teatral. Em diálogo com ideias de pensadores da teatralidade como Josette Feral e Óscar Cornago, o artigo se propõe a pensar o espectador dessa cena que se assume enquanto cena. A mediação palco/plateia pode ser feita apenas pelos próprios funcionamentos, jogos, materialidades e regras dessa cena? A relação entre o público e a obra a partir da teatralidade é o objeto de estudo deste artigo.

Palavras-chave: Espectador, Pedagogia, Teatralidade.

\section{Abstract}

This article analyzes an experience conducted with participants of a pedagogical process starting from the exposure of scenic artifice and theatrical lie. In dialogue with ideas of theatre theoreticians, such as Josette Feral and Oscar Cornago, the article aims to comprehend the spectator of this scene which takes itself as scene. Can the stage/ audience mediation be made only by the scene's operation, games, materiality, and rules? The relationship between audience and work established by the theatricality is the subject of this article.

Keywords: Spectator, Pedagogy, Theatricality.

\section{Resumen}

En este artículo se evalúa una experiencia realizada con participantes de un proceso pedagógico a partir de la exposición de artificios escénicos y de la mentira teatral. En diálogo con ideas de los pensadores de la teatralidad como Josette Féral y Óscar Cornago, este artículo se propone a pensar al espectador de esta escena que se asume como escena. ¿Puede la mediación escenario/audiencia hacerse solamente por materialidades, juegos, reglas, operaciones que gobiernan esta escena? La relación entre el público y la obra a partir de la teatralidad es el objeto de este artículo.

Palabras clave: Espectador, Pedagogía, Teatralidad. 
Já não é o mundo visto como uma cena representada, mas como um mecanismo que produz representações e que nele o fundamental não é tanto o resultado dessas representações, mas sim o mecanismo em si mesmo. A pergunta frente a uma representação, ou seja, frente a uma obra artística ou um determinado fenômeno social já não é, portanto, o que significa, mas sim como funciona. (CORNAGO, 2005, p. 7).

A cena contemporânea vem propondo diversos modos de percepção. $O$ espectador é constantemente desafiado e posto na contramão da imagem de uma plateia passiva e abandonada em suas poltronas. Isso não significa que um convite ao público não possa se resguardar à ação de "ver", sem necessariamente exigir certa participação efetiva na cena. Conforme as ideias de Josette Féral (2002a), a teatralidade existe somente se há o olhar de alguém dirigido ao evento. É o espectador que dá ao objeto seu grau de teatralidade. A cena se esforça, tem a intenção de ser teatral, mas a teatralidade efetivamente acontece se há o olho de um terceiro.

Este artigo pretende investigar possíveis diálogos entre teatralidade e pedagogia. Ele se propõe a pensar a relação do espectador com uma cena assumidamente artificial, calcada na forma do teatro propriamente dito. Da materialidade teatral em si, podem-se produzir outros modos de percepção. Um artifício escancarado é capaz de ressaltar a diferença entre a realidade da cena e a realidade da vida. Ao ser exibido, ele pode sublinhar o caráter de produção da obra, relativizando-a menos como realidade provável do que como construção possível. Uma vez mostrada, essa operação de artesania teatral disponibiliza novas possibilidades de vida, distintas das cotidianas.

Féral (2009) propõe o pensamento de que a teatralidade aparece quando o espectador percebe a intenção teatral, quando ele sabe que é teatro. Esse saber modifica o olhar do espectador, que passa a ver o espetacular onde havia apenas um evento cotidiano. Há um momento de transformação do cotidiano em ficção, um processo de semiotização do espaço e deslocamento de significados, fazendo surgir um simulacro sobre os corpos dos performers. A teatralidade, segundo Féral, está na intenção de fazer teatro, uma intenção que deve ser compartilhada com o espectador a fim de que ele a reconheça. Dessa forma, a teatralidade não está sempre no objeto que é visto, não está necessariamente no simulacro, mas sim no olhar do espectador. 
Ela é resultado de um ato consciente que pode partir do artista, mas também do espectador que a cria a partir de seu olhar. O cenário, o figurino e o gesto do ator são elementos que ajudam no reconhecimento da teatralidade, mas ela pode ser identificada sem esses elementos. Mesmo não sendo teatro, o espectador pode olhar para um evento e enxergar teatralidade, construindo um espaço potencialmente teatral.

Isso quer dizer que, simplesmente pelo olhar, pode-se constituir uma clivagem no espaço, enquadrando e colocando o outro como emissor de signos, situando o objeto ou a pessoa em uma alteridade. Se o outro está no mesmo espaço do espectador, não existe teatro. Assim, a teatralidade é, como afirma Féral (2009), um posicionamento do sujeito em relação ao mundo. O olhar do espectador é duplo, pois nunca se deixa ser totalmente envolvido pela representação. Esse é, para Féral, o paradoxo do espectador: "crer no outro sem totalmente crer. Vê-se o homem e o ator, a materialidade e a potência simbólica, a realidade e a ficção. Essa duplicidade é necessária para que haja teatralidade (FÉRAL, 2009)". Se não ocorrer a clivagem entre o espaço cotidiano, real, e o espaço potencial, ficcional, o espectador se mantém no primeiro espaço, afastando qualquer possibilidade de teatralidade.

[A teatralidade] é consequência de um processo dinâmico de teatralização produzido pelo olhar que postula a criação de outros espaços e outros sujeitos. Esse processo construtivo resulta de um ato consciente que pode partir tanto do performer no sentido amplo do termo - ator, encenador, cenógrafo, iluminador - quanto do espectador. Portanto, a ensaísta sustenta que a teatralidade tanto pode nascer do sujeito que projeta um outro espaço a partir de seu olhar quanto dos criadores desse lugar alterno, que requerem um olhar que o reconheça. Mas é mais comum que a teatralidade nasça das operações reunidas de criação e recepção. De qualquer forma, ela é o fruto de uma disjunção espacial instaurada por uma operação cognitiva ou um ato performativo daquele que olha (o espectador) e daquele que faz (o ator) Tanto a ópsis quanto a práxis é um vir a ser que resulta dessa polaridade. (FERNANDES, 2010, p. 123).

De modo semelhante, Oscar Cornago (2005) também defende o caráter processual do teatro: se não houver alguém olhando, a teatralidade deixa de existir; só há essa realidade enquanto ela estiver acontecendo, funcionando. Cornago exemplifica sua idéia com o ato do disfarce. Ninguém se disfarçaria 
se não para ser visto por outra pessoa. Ao mesmo tempo, se o disfarce estivesse tão bem realizado, que quem olha não descobrisse que por detrás do personagem se esconde um ator, a representação deixaria de ser teatral, o engano seria invisível e o jogo teatral não existiria. Há um sistema de tensões gerado pelo que ele chama de distância de teatralidade entre o que o espectador vê e o que o espectador percebe de escondido por trás do que está vendo. A teatralidade funciona no espaço entre esses dois campos e só pode ser construída, ou melhor, descoberta, pelo olhar do outro.

Para Cornago, a teatralidade não é a representação, mas sim a apresentação da representação; é a representação representando a si mesma que põe à luz os procedimentos que poderiam passar despercebidos; é um redobramento da representação que se faz mais consciente e faz o espectador desfrutar o fato de ver seus mecanismos, seus jogos de artifício e os desequilíbrios de identidade de seus atores. A verdade de uma e de outra não coincidem: "A verdade da representação fica desvelada como um engano ao lado da verdade performativa da teatralidade. Sua verdade é seu ser como jogo, fingimento e dissimulação e a realidade não é a realidade da representação, mas sim a realidade do processo de representação." (CORNAGO, 2005, p. 5).

Dessa forma, aqui interessa a relação da teatralidade com a pedagogia, uma vez que o olhar de um terceiro é fundamental para identificar a engenharia do funcionamento da própria ficção exposta "em carne viva", podendo alimentar a imaginação de quem faz e de quem assiste.

\section{A arquitetura do engano}

Nas perspectivas de Féral e Cornago, ao espectador é atribuído valor somente pela sua função de olhar, ver, observar. O espectador é aquele que identifica, percebe, cria espaços de ficção, imagina histórias. No caso da cena trabalhada com artifícios expostos, o olhar do público é fundamental para que se complete a cadeia da investigação da teatralidade.

Em 2010, coordenei a montagem do espetáculo O Inspetor Geral, de Nicolai Gogol, como formatura da turma da escola profissionalizante Incenna. A teatralidade assumida enquanto tal seria mote da linguagem da encenação. Além disso, por se tratar de uma trama em que os personagens se equivo- 
cam, se camuflam, se enganam, interpretam outros, subornam, mentem e escondem, o grupo decidiu focar no teatro e seus artifícios como o grande tema do espetáculo. Assim, por um lado, haveria a camada da narrativa em que Ivan Khlestakov é confundido com um inspetor geral, se aproveitando da situação e comendo do bom e do melhor em uma pequena província russa. Por outro, esse engano temático também seria trazido para o campo formal em que os atores assumiriam o jogo entre ficção e realidade, lembrando o espectador de que se encontra diante de uma obra de teatro, revelando seus modos de construção e, ao mesmo tempo, convidando-o para se aventurar em um universo russo com personagens esquisitos, mancos e patéticos. Ambas as formas, para o grupo, eram características de teatralidade: ficção que envolve e ficção que se mostra linguagem.

Esse parecia ser, a princípio, uma cena em que o espectador é levado em consideração na construção teatral. O desnudamento dos artifícios cênicos não quer enganar o espectador, não quer fingir que ele não está diante do teatro. Ao mesmo tempo, esse processo engana e finge, convida quem olha a se aventurar em um espaço de ficção, diferente do cotidiano. Os mecanismos da cena, no mesmo instante, mentem e se revelam, convidam o espectador $\mathrm{e}$ o ator a deixar-se enganar. Sua estrutura vai sendo revelada e entendida ao longo de sua construção. É um engano que pede ao espectador que se deixe enganar. Se, por um lado, o espectador realmente se enganar, acreditando que está diante da realidade, ou se, por outro, o espectador duvidar completamente a ponto de abandonar seu posto de espectador de ficção, não há teatro. Para haver teatralidade, são necessários procedimentos que façam que o espectador, sabendo que está diante de uma mentira, de uma construção, se deixe enganar: não se engane nem duvide, mas se deixe enganar, se deixe arrastar pela ficção.

Cornago diz que o importante não é dar verossimilhança ao resultado final, ou seja, deve-se aceitar a verdade da representação, já que ela se assume desde o princípio como falsa. O que precisa ser crível é o processo, o mecanismo de tensões entre o que se vê e o que se esconde: "A teatralidade é uma maquinaria que torna visível umas coisas e oculta outras, mas o importante não é a imagem final, produto da representação, mas sim o funcionamento do próprio mecanismo, colocado em manifesto no espaço." (CORNA- 
$\mathrm{GO}, 2005$, p. 8). As estratégias investigadas no processo de montagem de $\mathrm{O}$ Inspetor Geral apresentaram uma estrutura de teatralidade em que havia uma linguagem menos realista e mais pautada na ostentação da realidade de seus mecanismos: o efeito de realidade se desloca para verdade do mecanismo; é um jogo visível de fingimentos e enganos que assume seu caráter falso. Dessa forma, segundo Cornago, o teatro pode ser uma reflexão sobre a vida e a realidade que, por meio da exposição dos seus mecanismos de construção, propõe um constante processo de revisão de verdades, ideologias e discursos da sociedade candidatos a se tornar verdades universais.

Em um encontro dentro do processo de investigação da linguagem teatral e do artifício escancarado durante a montagem de $O$ Inspetor Geral, propus uma saída para o parque Ibirapuera. Os atores foram de figurino, já entendendo que suas ações poderiam ser contaminadas por um caráter mais poético e imagético, mais extracotidiano. Tendo chegado no parque, fizemos algumas experiências como uma composição plástica nas rampas da bienal. Em seguida, propus irmos para um espaço debaixo de inúmeras árvores, cujo chão era coberto de folhas secas e, ali, eles poderiam experimentar o exercício do coro dos personagens em que quem está à frente do coro, o corifeu, assume a liderança dos movimentos como personagem; ao mudar de direção, muda-se o corifeu.

Enquanto os atores faziam a ação, um grupo grande de crianças de uma escola pública com suas professoras se acercou para assistir o exercício e se colocou em uma posição de espectadores, como quem estivesse assistindo uma cena. Aos poucos, sem ninguém falar ou pedir nada, as crianças começaram a assistir mais de perto o coro dos personagens, tirando fotos, caminhando junto, comentando, dando risada. De repente, elas se incluíram no coro: entenderam a regra do jogo de que um faz e os outros repetem e sentiram-se convidados a jogar junto. Então, um coro de mais ou menos 40 pessoas - personagens russos - passeava por uma clareira do parque Ibirapuera. Ainda que as crianças nunca tenham assumido a posição de corifeu, liderando o movimento, se incluíram efetivamente na ação, abandonando sua condição daquele que assiste.

Esse encontro foi muito fértil para nossa pesquisa, pois pudemos experimentar na prática a potência de um artifício escancarado sendo reconhe- 
cido pelo espectador e o convidando a adentrar na ação. As crianças, ainda assistindo de longe, tiveram prazer em decodificar os modos de construção daquele jogo. $O$ artifício Ihes revelou a arquitetura daquela ficção sem que ela tivesse ficado perdida. No mesmo instante, no mesmo segundo, os espectadores se aventuraram em um universo ficcional extracotidiano e procuraram entender sua carpintaria, suas formas de existir. Criou-se uma cumplicidade com as crianças que decodificaram os procedimentos de construção, ao mesmo tempo que foram envolvidas nesse mundo outro que é o mundo-ficção.

Além disso, a teatralidade que ali estava mostrando-se em carne viva só completou-se em sua existência a partir da identificação e do olhar das crianças. Provavelmente, elas não nomeiam aquele fenômeno como teatralidade, mas, sem dúvida, adentraram no jogo porque ali encontraram uma fissura no espaço cotidiano, uma clivagem, como diz Féral (2002a), uma entrada para um lugar outro, um lugar ficcional. Para Féral, a teatralidade é definida por suas capacidades de transformação do real, de transgressão do cotidiano, de representação e semitização do corpo e do sujeito para criar territórios de ficção.

O que a teatralidade pode trazer ao campo da pedagogia é a possibilidade de trabalhar com a inserção do espectador no próprio universo da ficção da obra, sem nunca esquecer de que aquilo é uma construção. $O$ figurino russo, a gestualidade inventiva e não cotidiana do coro e a organização do coletivo e a maneira como ele se escuta podem se configurar como distância do que é considerado comum. Outros modos de olhar o mundo podem ser inventados a partir da ficção do teatro, quando apresentada enquanto tal, visivelmente separada da realidade. $O$ teatro é, aqui, lugar de liberdade em relação às imagens do cotidiano, de imaginação de outros mundos. $O$ experimento do Ibirapuera possibilitou aos participantes explorar e olhar o mundo de maneiras outras, de maneiras não cotidianas, de maneiras teatrais.

As crianças, ao identificar os artifícios e as regras do jogo, adentraram no espaço de ficção sem que ninguém precisasse informar, avisar, ensinar, mostrar nada. O próprio mecanismo lúdico foi o mediador da experiência entre os atores e os espectadores. Por mais que os espectadores tenham transgredido a fronteira da plateia, ainda sim mantiveram-se na "condição de espectador" daquele terceiro que olha, que identifica a teatralidade, que percebe 
os mecanismos, que decodifica. As regras do jogo, quando aparentes, podem mediar a experiência artística.

\section{Referências bibliográficas}

BOAL, A. Teatro do oprimido e outras poéticas políticas. Rio de Janeiro: Civilização Brasileira, 1975.

Técnicas latino-americanas de teatro popular. São Paulo: Hucitec, 1979.

CORNAGO, O. Qué es la teatralidad? Paradigmas estéticos de la modernidad.

Telondefondo - Revista de Teoria y Crítica Teatral, Buenos Aires, n. 1, p. 5-26, ago. 2005.

FÉRAL, J. Performance and theatracality: the subject demystified. In: MURRAY, T. (ed.). Mimesis, masochism \& mime: the politcs of theatricality in contemporary french thought. Ann Arbor: University of Michigan, 1997.

Foreword. Substance, v. 31, n. 2, p. 3-13, 2002a. https://muse.jhu.edu/ (accessed June 6, 2016).

Theatricality: the specificity of theatrical language. Substance, v. 31, n. 2/3, p. 94-108, 2002b.

Por uma poética da performatividade: o teatro performativo. Sala Preta, v. 8, p. 197-210, 2008.

Teatro performativo e pedagogia. Sala Preta, v. 9, p. 255-267, 2009.

FERNANDES, S. Teatralidades contemporâneas. São Paulo: Perspectiva, 2010.

PAVIS, P. Dicionário de teatro. São Paulo: Perspectiva, 1999.

La théatralité em Avignon. In: Vers une théorie de la pratique théâtrale.

Paris: Septentrión, 2000.

Recebido em 31/03/2016

Aprovado em 12/05/2016

Publicado em 30/06/2016 